i. a memorial in a churchyard is not intended to be a judgment on the worthiness of the deceased or to reflect how loved or appreciated he or she was by family or others. If it were otherwise, those who wished to show their love and appreciation of the deceased would inevitably seek permission for more elaborate and grandiose memorials;

ii. the deceased's desire that she had a heart-shaped memorial (and equally an applicant's own assessment of what is a worthy memorial to a loved one) cannot weigh heavily in the determination as to whether such a memorial should be permitted. If it were otherwise, there could be no effective system of regulation of memorials in churchyards;

iii. a memorial cannot be justified simply because it is said that it will meet the pastoral needs of the deceased's family.

The application was refused, but the petitioners were given the opportunity to submit an application for a memorial with a heart etched onto a standard-shape stone at the suggestion of the DAC. [WA]

doi:10.1017/So956618X10001018

\title{
Re St Mary the Virgin, Ashford
}

Canterbury Commissary Court: Walker Com Gen, June 2010 Reordering - government funding - 'adverse effect'

A faculty was granted for a major reordering of the interior of the church, to include the replacement of the dais and seating in the nave, the upgrading of the heating, lighting, kitchen and lavatory facilities, improvement of disabled access, internal redecoration and the relocation of the font and pulpit. At a late stage the petitioners made an additional application for the installation of a ground source heat pump and rainwater harvesting tank, with the approval of the planning authority. Funding for the proposed project had been made available through the government's Growth Area Fund, with the support of Ashford Borough Council and the agency Ashford's Future, both of which bodies were petitioners along with the incumbent. The DAC noted that the proposed works would affect the character of the building, but recommended the scheme. The Victorian Society and an individual parishioner formally opposed the application, which was heard in open court. The commissary general applied the Bishopsgate questions, as they have developed, and as summarised by Hill Ch in Re St Mary, Newick (2009) 11 Ecc LJ 127, an approach commended by the Court of Arches in Re St Peter, Draycott (2009) 11 Ecc LJ 365. He found that the petitioners had overwhelmingly shown that the proposed works were necessary. He was only just convinced that they would not adversely affect the character 
of the building, but that even if they had, the necessity shown would have outweighed the adverse effect. ${ }^{3}$ [WA]

doi:10.1017/So956618X1000102X

\section{Hashwani v Jivraj}

Court of Appeal: More-Bick, Aikens and Buxton LJJ, June 2010 Arbitration - Equality (Religion and Belief) (Amendment) Regulations 2003

The court heard an appeal against the judgment of David Steel J sitting in the Commercial Court (noted at (2010) 12 Ecc LJ 121). The parties had been business associates who had agreed that if arbitration in the case of the winding up of their joint venture were to take place that the arbitrator appointed must be a member of the Ismaili Muslim community. One party had appointed an arbitrator from outside that community. The Commercial Court had held that the Equality (Religion and Belief) (Amendment) Regulations 2003 did not apply as an arbitrator was not an employee as covered by the regulations and thus that the appointment of an arbitrator from outside the community was void. The Court of Appeal upheld the appeal in part. The 2003 Regulations did apply to the appointment of arbitrators and being a member of this particular community was not a genuine occupational requirement under the regulations for carrying out the task. However, the striking out of the requirement for any arbitrator to be an Ismaili Muslim was held to invalidate the whole of the pertinent clause of the parties' agreement. Thus the ruling that the appointment of the arbitrator in question was void was upheld. [WA]

doi:10.1017/So956618X10001031

\section{Re St Andrew, Sedbergh \\ Bradford Consistory Court: Walford Ch, July 2010 \\ Cross - aesthetics - doctrinal objections}

The petitioners sought a faculty to hang an ebony and ivory cross above the pulpit. Seventeen of the twenty-two PCC members present had voted in favour of the proposal and four against. The DAC supported the petition. One of the PCC members who had voted against the proposal objected to the grant of a faculty on doctrinal and aesthetic grounds. No other objections had 